Jurnal Sains Riset (JSR)

p-ISSN 2088-0952, e-ISSN 2714-531X

http://journal.unigha.ac.id/index.php/JSR

DOI. $10.47647 /$ jsr.v10i12

\title{
PERAN KEPEMIMPINAN DALAM MENINGKATKAN KINERJAPEGAWAI PADA KANTOR URUSAN AGAMA DI KECAMATAN TANGSE KABUPATEN PIDIE
}

\author{
Awaluddin $^{(1)}$, Zulfikar $^{(2)}$ \\ Program Studi Ilmu Administrasi Negara, Fakultas Ilmu Administrasi Universitas Jabal Ghafur \\ Email : awaluddin@unigha.ac.id
}

\begin{abstract}
ABSTRAK
Sumber daya manusia merupakan faktor yang sangat penting dalam sebuah organisasi baik organisasi dalam skala besar maupun kecil yang dijalankan oleh seorang pemimpin dapat berperan di dalam melindungi beberapa isu pengaturan organisasi yang tidak tepat dalam menditribusikan kekuasaan yang menjadi penghalang tindakan yang efektif, kekurangan berbagai macam sumber, prosedur yang dianaggap buruk, dan sebagainya yaitu problemproblem organisasi yang lebih bersifat mendasar oleh karena peranan sentral kepemimpinan dalam organisasi tersebut, Adapun rumusan masalah dalam penelitian ini adalah bagaimana peran kepemimpinan dalam meningkatkan kinerja pegawai pada Kantor Urusan Agama di Kecamatan Tangse, Apa saja hambatan-hambatan dalam meningkatkan kinerja pegawai di kantor urusan agama di kecamatan Tangse,Upaya upaya apa saja yang dilakukan untuk meningkatkan kinerja pegawai, Objek penilitian yang kami ambil merupakan penilitian lapangan dengan menggunakan meode kualitatif. Adapun tujuan dalam penelitian ini adalah bagaimana peran kepemimpinan dalam meningkatkan kinerja pegawai pada Kantor Urusan Agama di Kecamatan Tangse, Apa saja hambatan-hambatan dalam meningkatkan kinerja pegawai di kantor urusan agama di kecamatan Tangse, upaya upaya apa saja yang dilakukan untuk meningkatkan kinerja pegawai, Objek penilitian yang kami ambil merupakan penilitian lapangan dengan menggunakan meode kualitatif. Dari hasil penelitian ini mendapatkan jawaban bahwa peran pemimpin atau Kepala Kantor Urusan Agama Tangse dalam menjalankan perannya sebagai figurehead dimana kepala rajin dalam melaksanakan kegiatan-kegiatan yang bersifat legal dan sosial dalam meningkatkan kinerja pegawainya, Kepala KUA patut dan layak untuk dicontohkan pegawainya dalam menjalankan organisasi dengan sungguh-sungguh. Dan hasil penelitian juga menunjukkan bahwa kepala KUA Kecamata Tangse dalam menjalankan peran pemimpin bersifat interpersonal yang diukur berdasarkan figur sudah cukup baik. Terbukti kepala KUA kecamatan Tangse dapat menjalankan perannya sebagai figurehead, yakni peranan yang dilakukan untuk mewakili organisasi yang dipimpinannya di dalam setiap kesempatan dan persoalan yang timbul secara formal.
\end{abstract}

Kata Kunci : Kepemimpinan, Kinerja Pegawai 
Jurnal Sains Riset (JSR)

p-ISSN 2088-0952, e-ISSN 2714-531X

http://journal.unigha.ac.id/index.php/JSR

DOI. $10.47647 /$ jsr.v10i12

\section{PENDAHULUAN}

\subsection{Latar Belakang}

Sumber daya manusia merupakan faktor yang sangat penting dalam sebuah organisasi baik dalam skala besar maupun kecil.pada organisasi berskala besar sumber daya manusia sangat dipandang sebagai sumber yang sangat menentukan dalam proses pengembangan usaha, peran sumber daya manusia menjadi sangat penting karena suatu tujuan dalam organisasi dapat berhasil atau tidak tergantung faktor manusia yang berperan menjalankannya, melaksanakan dan mengendalikan organisasi yang bersangkutan. untuk kemajuan dan mencapai tujuan yang telah di tetapkan.

Kepemimpinan sebagai salah satu fungsi manajemen merupakan hal yang sangat penting untuk mencapai tujuan organisasi.Kepemimpinan dipaksa menghadapi macam faktor seperti struktur atau tatanan, koalisi, kekuasaan atau kondisi lingkungan organisasi, sebaliknya kepemimpinan rasanya dapat dengan mudah menjadi suatu permasalahan untuk menyelesaikan terhadap persoalan apa saja yang sedang menimpa suatu organisasi. masalah kepemimpinan merupakan hal yang sangat luas dan memainkan peranan yang sangat penting dalam bidang pendidikan dalam suatu organisasi, bahkan dalam kehidupan sehari-hari.Setiap masyarakat timbul dua kelompok yang berbeda peran sosialnya, yaitu yang memimpin sebagai golongan kecil dan sebagai golongan yang besar, disinilah membutuhkan pemimpin untuk tujuan suatu organisasi yang dibuat tidak akan ada artinya karena tidak ada yang bertindak sebagai penyatu terhadap berbagai kepentingan.

Kedisiplinan adalah suatuhal hal yang paling penting di gerakkan oleh seorang pimpinan karena tanpa adanya disiplin semua kegiatan yang dilakukan hasilnya tidak akan memuaskan dan tidak sesuai dengan harapan. Dalam hal ini dapat mengakibatkan kegagalan dalam pencapaian suatu tujuan dan sasaran organisasi di kantor urusan agama menghambat jalanya program-program organisasi yang di buat, pegawai yang kurang disiplin akan sulit meningkatkan produktivitas dan tidak mungkin merealisasikan pencapaian tujuan yang ditetapkan pada kantor urusan agama sebelumnya maka dari itu perlu peran penuh kepemimpinan dan kesadaran i para pegawai untuk bekerja lebih disiplin untuk memenuhi dan mentaati peraturan yang ada dengan kata lain untuk mencegah pelannggaran, pemberian sanksi kepada para pegawai dan bertujuan agar pegawai tidak mengulangi kesalahan yang telah dilakukan.

Berdasarkan latar belakang di atas maka penulis tertarik untuk memilih judul penelitian dalam bentuk proposal skripsi dengan judul: "peran kepemimpinan dalam meningkatkan kinerja pegawai pada kantor urusan agama pada kecamatan Tangse".

\subsection{Rumusan Masalah}

1. Bagaimana peran kepemimpinan dalam meningkatkan kinerja pegawai pada Kantor Urusan Agama di Kecamatan Tangse?

2. Apa saja hambatan-hambatan dalam meningkatkan kinerja pegawai di kantor urusan agama di kecamatan Tangse.

\subsection{Tujuan Penelitian}

1) Untuk mengetahui bagaimana peran kepemimpinan dalam meningkatkan kinerja pegawai pada Kantor Urusan Agama di Kecamatan Tangse?

2) Untuk mengetahui apa saja hambatan-hambatan dalam 
Jurnal Sains Riset (JSR)

p-ISSN 2088-0952, e-ISSN 2714-531X

http://journal.unigha.ac.id/index.php/JSR

DOI. $10.47647 /$ jsr.v10i12

meningkatkan kinerja pegawai di kantor urusan agama di kecamatan Tangse.

\section{TINJAUAN PUSTAKA}

\subsection{Peran Kepemimpinan}

Peranan pimpinan dalam suatu organisasi itu sangatlah penting karena keberadaan pimpinan yaitu menjadi palang pintu atau menjadi salah satu ujung tombak dari keberhasilan dalam berorganisasi.Salah satu tugas atau peran piminan yaitu harus bisa mengelola konflik dalam organisasi yang dipimpinnya sehingga setiap konflik itu bisa diselesaikan dengan baik dan tidak ada yang merasa dirugikan. Pimpinan adalah seseorang yang bekerja melalui orang lain dengan mengoordinasikan kegiatan-kegiatan mereka guna mencapai sasaran organisasi.

Peranan adalah suatu penampilan atau tingkah seorang pemimpin atau organisasi berdasarkan jabatan yang dimilikinya sesuai dengan linngkungan dalam melaksanakan tugas kerjanya.

Sehubungan dengan peranan maka gunawan (2010:41) mengatakan bahwa peranan menunjuk pada aspek dinamis dan status peranan memiliki dua arti yaitu:

a. Dari sudut individu berarti sejumlah peranan yang timbul dari berbagai pola yang didalamnya individu tersebut aktif.

b. Peranan secara umum menunjuk pada keseluruhan peranan itu dan menentukan apa yang dikerjakan seseorang untuk masyarakatnya serta apa yang diharapkan dari masyarakat itu.

Berdasarkan perana di atas maka kami dapat mengerti dan menyimpulkan bahwa peranan merupakan suatu tugas pokok dan kewajiban dalam organisasi atau masyarakat supaya dapan mencapai tujuan tertentu dimana target nya sudah jelas.

Adapun peranan pemimpin dalam tim adalah sebagai berikut:

a. Memperlihatkan gaya pribadi

b. Proaktif dalam sebagian hubungan

c. Mengilhami kerja tim

d. Memberikan dukungan timbal balik

e. Membuat orang terlibat dan terikat.

f. Memudahkan orang lain melihat peluang dan prestasi.

g. Mencari orang yang ingin unggul dan dapat bekerja secara kontruktif

h. Mendorong dan memudahkan anggota untuk bekerja.

i. Mengakui prestasi anggota tim

j. Berusaha mempertahankan komitmen

k. Menempatkan nilai tinggi pada kerja tim.

\subsection{Meningkatkan Kinerja Pegawai}

Pengertian kata kinerja menurut istilah Sedarmayanti (2011:259) Kinerja berasal kata dari kata "to perform" yang mempunyai pengertian "to do or carry out execute" yang artinya melakukan,menjalankan,melaksanakan dan "to execute or complete an undertaking" yang artinya melaksanakan atau menyempurnakan tanggung jawab. Kinerja dalam istilah psikologis tidak dapat di ukur secara jelas seperti yang dijelaskan menurut Suryabrata dalam yusrizal (2011:275) atribut psikologis tidak dapat diukur secara langsung,atribut psikologis hanya dapat diukur secara tidak langsung melalui respons yang dibuat oleh subjek pada waktu 
Jurnal Sains Riset (JSR)

p-ISSN 2088-0952, e-ISSN 2714-531X

http://journal.unigha.ac.id/index.php/JSR

DOI. $10.47647 /$ jsr.v10i12

subjek dihadapkan kepada perangsang tertentu.

Mathis dan Jackson (2011: 5) menyatakan bahwa kinerja merupakan rangkaian yang kritis antara strategi dan hasil organisasi, banyak faktor yang dapat mempengaruhi kinerja individu karyawan yaitu kemampuan mereka, motivasi, dukungan yang diterima, keberadaan pekerjaan yang mereka lakukan dan hubungan mereka dengan organisasi.

Dikemukakan pendapat menurut Marihot Tua Efendi dalam Anoki, (2010:29) menjelaskan bahwa kinerja merupakan hasil kerja yang dihasilkan oleh pegawai atau perilaku nyata yang ditampilkan sesuai perananya dalam organisasi.Kinerja merupakan hasil yang dicapai seseorang baik secara kualitas kuantitas sesuai dengan tugas da tanggunng jawab yang diberikan kepadanya. Kinerja seseorang dapat kita lihat melalui proses perjalanan karir seseorang baik di bidang organisasi,tingkat pendidikan, inisiatif terhadap sesame, pengalaman kerja dan juga dapat memotivasi karyawan itu sendiri,semakin besar hasil kerja seseorang makan umpan balik yang diperoleh orang itu sendiri.

Menurut Armstorng dan baron dalam Wibowo (2012:2) menjelaskan bahwa kinerja merupakan hasil pekerjaan yang mempunyai hubungan kuat dengan strategi organisasi, kepuasan konsumen dan memberikan kontribusi ekonomi.kinerja seorang pegawai mmerupakann hasil suatu kegiatan baik perorangan maupun berkelompok dalam melakuka suatu kegiatan dan menyempurnakan sesuai dengan tanggung jawabnya masing-masing.

Dari pendapat diatas maka dapat kami simpulkan bahwa kinerja merupakan hasil kerja yang dapat di capai baik secara perseorangan maupun kelompok dalam suatu organisasi kerja sesuai denagna manaha dan tanggung jawab masing-masing untuk mencapai tujuan organiasasi yang baik.

\subsection{Kantor Urusan Agama Tangse}

Kantor Urusan Agama adalah instansi terkecil Kementrian Agama yang ada di tingkat Kecamatan. KUA bertugas membantu melaksanakan sebagian tugas Kantor Kementrian Agama Kabupaten di bidang urusan agama islam di wilayah kecamatan. Pada masa pemerintahan Penduduk Jepang, tepatnya pada tahun 1943 Pemerintah Jepang di Indonesia mendirikan Kantor Shumubu (KUA) di Jakarta. Pada waktu itu yang ditunjuk sebagai Kepala Shumubu untuk wilayah Jawa dan Madura adalah KH. Hasim Asy'ari pendiri Pondok Pesantren Tebuireng Jombang dan pendiri jam'iyyah Nahdlatul Ulama.

Kelahirannya tidak dapat dipisahkan dengan dinamika perjuangan bangsa.Pada saat bangsa ini berjuang mempertahankan kemerdekaan yang baru saja diproklamirkan, Maka lahirlah Kementrian Agama.Pembentukan Kementrian Agama tersebut selain untuk menjalankan tugasnya sebagai penanggugjawab realisasi Pembukaan UUD 1945 dan pelaksanaan pasal 29 UUD 1945, juga sebagai pengukuhan dan peningkatan status Shumubu (Kantor Urusan AgamaTingkat Pusat) pada masa penjajahan Jepang. Berdirinya Kementrian Agama disahkan berdasarkan Penetapan Pemerintah Nomor : I/SD tanggal 3 Januari 1946 bertepatan dengan 2 Muharram 1364 H. Menteri Agama pertama adalah H.M. Rasyidi, BA. Sejak itu dimulailah penataan struktur di lingkungan Kementrian Agama.Pada tahap 
Jurnal Sains Riset (JSR)

p-ISSN 2088-0952, e-ISSN 2714-531X

http://journal.unigha.ac.id/index.php/JSR

DOI. $10.47647 /$ jsr.v10i12

ini, Menteri Agama H.M. Rasyidi mengambil alih beberapa tugas untuk dimasukkan dalam lingkungan Departemen Agama. 2 Tugas pokok Departemen Agama waktu itu ditetapkan berdasarkan Penetapan Pemerintah Nomor : 5/SD tanggal 25 Maret 1946 dan Maklumat Pemerintah Nomor 2 tanggal 24 April 1946 yang menyatakan bahwa tugas pokok Kementrian Agama adalah : menampung urusan Mahkamah Islam Tinggi yang sebelumnya menjadi wewenang Departemen Kehakiman dan menampung tugas dan hak mengangkat Penghulu Landraat, Penghulu Anggota Pengadilan agama, serta Penghulu Masjid dan para pegawainya yang sebelumnya menjadi wewenang dan hak Presiden dan Bupati. Disamping pengalihan tugas di atas, Menteri Agama mengeluarkan Maklumat Menteri Agama Nomor 2 tanggal 23 April 1946 yang menyatakan, bahwa:

Pertama, instansi yang mengurus persoalan keagamaan di daerah atau SHUMUKA (tingkat karesidenan) yang di masa pendudukan Jepang termasuk dalam kekuasaan Residen menjadi Djawatan Agama Daerah yang berada di bawah wewenang Kementrian Agama.

Kedua, Pengangkatan Penghulu Landraat (Penghulu pada Pengadilan Agama) Ketua dan Anggota Raad (Pengadilan) Agama yang menjadi hak Residen dialihkan menjadi hak Kementrian Agama.

Ketiga, Pengangkatan Penghulu Masjid yang berada dibawah wewenang Bupati dialihkan menjadi wewenang Kementrian Agama.Sebelum maklumat Mentri Agama dilaksanakan secara efektif, kelembagaan pengurusan agama di daerah berjalan sesuai dengan keadaan dan kebutuhan.Sejak jaman penjajahan, perangkat organisasi kelembagaan yang mengurus agama yang telah tersebar ke seluruh plosok tanah air, hingga tingkat kecamatan bahkan sampai desa.Perangkat ini bekerja sebagai tenaga sukarelawan (buka pegawai negeri).

\subsection{Hipotesis Penelitian}

Yang menjadi hipotesis dalam penilitian ini adalah partisipasi pemimpinan dalam meningkatkan kinerja pegawai pada kantor urusan agama di Kecamatan Tangse belum maksimal sabagaimana yang di harapkan.

\section{METODE PENELITIAN}

\subsection{Metode Penilitian}

Objek penilitian yang kami ambil judul tentang peran kepemimpinan dalam meningkatkan kinerja pegawai pada kantor urusan agama kecamatan tangse, penilitian ini merupakan penilitian lapangan dengan menggunakan meode kualitatif untuk mengetahui bagaimana peran seorang pemimpin dalam meningkatkan kinerja para pegawai.

\subsection{Lokasi Penilitian}

Lokasi penilitian yang di ambil oleh peneliti pada Kantor Urusan Agama Kecamatan Tangse Kabupaten Pidie.

\subsection{Teknik Pengumpulan Data}

Miles dan Huberman dalam Sugiyono, (2010: 338) mengemukakan dalam penelitian kualitatif, analisis data dilakukan sejak awal penelitian dan selama proses penelitian dilaksanakan. Data diperoleh, kemudian dikumpulkan untuk diolah secara sistematis, dimulai dari wawancara, observasi, mengedit, mengklasifikasi, mereduksi, selanjutnya 
Jurnal Sains Riset (JSR)

p-ISSN 2088-0952, e-ISSN 2714-531X

http://journal.unigha.ac.id/index.php/JSR

DOI. $10.47647 /$ jsr.v10i12

aktivitas penyajian data serta menyimpulkan data.

Analisis merupakan penyusunan terhadap data yang telah diolah untuk mendapatkan suatu kesimpulan, dalam menganalisis data penulis menggunakan metode analisis kualitatif yaitu suatu analisis yang menggambarkan keadaan dan peristiwa secara menyeluruh dengan uraian yang dilakukan peneliti berdasarkan pada peraturan Perundang-Undangan, pandangan pakar, termasuk pengalaman peneliti dan penjelasan penulis dilapangan.

\section{Sumber:Analisis Data Kualitatif}

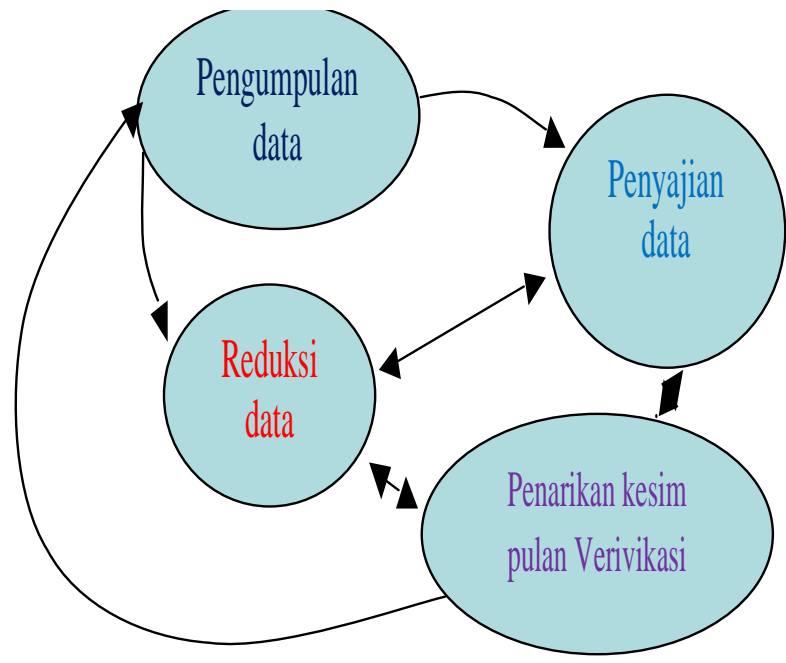

Gambar1: Analisa Interaktif dari Miles dan Huberman dalam

Sugiyono ( 2010: 338)

Penarikan Kesimpulan, penarikan kesimpulan dilakukan selama proses penelitian berlangsung seperti halnya proses reduksi data, setelah data terkumpul cukup memadai maka selanjutnya diambil kesimpulan sementara dan setelah data benar-benar lengkap maka diambil kesimpulan akhir.

\subsection{Teknik Analisi Data}

Menurut Sugiyono (2014: 333) Yang mengemukakan pendapatnya bahwaAnalisis data adalah proses mencari dan menyusun secara sistematis data yangdiperoleh dari hasil wawancara, catatan lapangan dan dokumentasi dengan caramengorganisasikan data kedalam kategori, menjabarkan kedalam unitunit,menyusun pola, memilih mana yang penting dan yang akan dipelajari dan membuat kesimpulan sehingga mudah dipahami oleh diri sendiri maupun orang lain.

Analisis merupakan penyusunan terhadap data yang telah diolah untuk mendapatkan suatu kesimpulan. Dalam menganalisis data penulis menggunakan metode analisis kualitatif yaitu suatu analisis yang menggambarkan keadaan dan peristiwa secara menyeluruh dengan uraian yang dilakukan peneliti.

\section{HASIL PENELITIAN DAN PEMBAHASAN}

\subsection{Pembahasan}

\subsubsection{Peran kepemimpinan dalam meningkatkan kinerja pegawai pada Kantor Urusan Agama di Kecamatan Tangse.}

Kepemimpinan

merupakan kemampuan seorang pemimpin yang dapat memengaruhi orang lain agar bergerak sesuai dengan kehendak pemimpin yang mengarah pada pencapaian tujuan yang telah ditentukan dalam organisasi. Kepemimpinan juga mempunyai peran terhadap motivasi kerja karyawan yaitu dengan adanya pemimpin dapat mengarahkan pegawai 
Jurnal Sains Riset (JSR)

p-ISSN 2088-0952, e-ISSN 2714-531X

http://journal.unigha.ac.id/index.php/JSR

DOI. $10.47647 /$ jsr.v10i12

menuju pencapaian tujuan perusahaan, mendorong pegawai untuk bersinergi terhadap pekerjaan, meningkatkan kinerja menjadi lebih baik dari sebelumnya, dan memberikan rasa tanggung jawab serta loyalitas yang tinggi terhadap perusahaan.

Pemimpin identik dengan pengaruh, terutama pengaruh yang memberikan inspirasi bagi para bawahan mereka. Visi dan misi sangat penting untuk memungkinkan orang lain merasa seolaholah pekerjaan mereka memiliki tujuan dan makna di luar tugas yang mereka lakukan setiap hari. Terkadang para pemimpin harus membantu staf mereka untuk mengenal gambaran besar dari tujuan dari organisasi atau perusahaan, tempat di mana mereka bekerja. Mengkomunikasikan gambaran besar secara teratur akan membantu memperkuat alasan keberadaan organisasi. Tidak hanya mengkomunikasikan visi misi, tetapi juga bagaimana membuka pemikiran tentang berbagai ide dan gagasan dari pegawai atau bawahan untuk kesuksesan bersama.

Pemimpin yang baik tetap memiliki rasa ingin tahu yang besar secara intelektual dan bertekad untuk belajar.Mereka ingin tahu dan selalu mencari ide, wawasan dan informasi baru.Inovasi baru, inspirasi dan berbagai strategi jitu bisa datang dan masuk dalam pikiran melalui setiap kondisi apapun dan dari berbagai tempat mana pun.

Kaitannya peran pemimpin dalam meningkatkan kinerja pegawai, pendelegasian tugas atau wewenang ini juga dapat digunakan untuk menjadi tolak ukur seorang pemimpin dalam memberikan penilaian kepada bawahanya. Kemampuan serta pemahaman tugas merupakan parameter yang dapat menunjukan seberapa jauh pegawai tersebut dapat mengerti apa yang ditugaskan oleh pimpinanya.

Pembagian tugas tersebut juga dapat memberikan tambahan pengalaman terhadap bawahan sehingga akan lebih terampil dan dapat menjadikan pribadi pada masingmasing pegawai lebih bisa bertanggung jawab terhadap pekerjaan yang diberikan. Sehingga dapat di tarik kesimpulan bahwa dengan adanya proses pendelegasian tugas antara pimpinan dan bawahan memiliki sinergi yang dapat menciptakan kualitas pekerjaan yang lebih baik dan peran camat sebagai pemimpin juga telah dapat dirasakan oleh pegawainya

Dengan komunikasi yang baik juga akan mendorong motivasi pegawai karena secara tidak langsung kebiasaan-kebiasaan komunikasi yang lancar akan memberikan rasa nyaman bagi pegawai sehingga mereka akan merasa senang dan lebih semangat dalam bekerja. Dalam menjalankan komunikasi itu sendiri piminan juga sering kali langsung terjun ke ruangan meskipun hanya sekedar berkeliling untuk komunikasi yang mungkin tidak ada kaitanya dengan kepentingan pekerjaan.

Kemampuan kinerja merupakan salah satu kreteria yang penting yang harus dimiliki oleh setiap pegawai yang ada dalam organisasi. Hasil wawancara yang dilakukan oleh peneliti dengan kepala KUA, bahwa selama ini kemampuan yang dimiliki oleh masing-masing personil pegawai kantor sudah cukup baik dan memuaskan.

Hal ini dapat dilihat dari kinerja pegawai yang sudah mampu menyelesaikan pekerjaan di bidang masing-masing sesuai dengan tupoksi yang ada serta rasa tanggug jawab yang tinggi untuk melayani kebutuhan masyarakat. Dan untuk menambah wawasan atau pengalaman bagi 
Jurnal Sains Riset (JSR)

p-ISSN 2088-0952, e-ISSN 2714-531X

http://journal.unigha.ac.id/index.php/JSR

DOI. $10.47647 /$ jsr.v10i12

pegawai, Pak camat juga merasa puas dengan kemampuan personilnya dalam memberi ide atau sumbangan yang berupa gagasan baru untuk program kantor.

Untuk mengembangkan kualitas dan keterampilan agar semakin efektif dalam bekerja dan meningkatkan pengembangan organisasi, maka Anda perlu menginvestasikan waktu, tenaga dan juga uang Anda untuk mengembangkan bawahan.Kunci untuk mengembangkan pegawai secara aktif adalah menetapkan tujuan yang relevan dan yang dapat dicapai.Yang terpenting, yaitu dorongan kepada pegawai untuk mencari peluang pengembangan profesional di luar tempat kerja.

Peran yang diperlukan untuk menjalankan sejumlah kegiatan yang bersifat legal dan sosial dan bertanggung jawab untuk memotivasi dan mengarahkan bawahan dalam peran ini pemimpin menjalankan perannya sebagai Leader yang dimana kepala terus melakukan motivasi terhadap pegawai-pegawai yang ditemuinya dan mengawasi kemajuan pegawainya serta memberikan pengarahan yang efektif bagi pegawainya.

Kewajiban pimpinan selalu mendorong para rekan-rekan pegawai untuk membuat inovasi-inovasi dan beliau juga turut mengeluarkan ide-idenya dan langsung dikatakan kepada kami apabila beliau menganggap itu penting untuk langsung dilaksanakan seperti membuat lingkungan kerja kami nyaman dan santai apabila beliau melihat pegawainya saat bekerja terlihat kaku beliau pasti biasanya membuat semacam pengumaman bahwa hari minggu nanti akan ada lombalomba tiap bidang untuk membuat kami lebih bersemangat lagi."
Adapun penilaian pegawai kantor urusan agama terhadap kepala dalam peranya sebagai pemimpin selama ini di ukur dari 4 kajian secara universal dan bisa mejadi bahan renungan bagi kita semua termasuk bagi penulis sendiri apakah kita telah melaksanakan fungsi Kepemimpinan secara paripurna?

1) Perilaku dasar seorang pemimpin, jika seorang pemimpin mampu memimpin perilakunya maka dia memang bisa diharapkan dan mampu memimpin pegawai yang dipimpinnya. kemampuan memimpin perilaku adalah, apakah sang pemimpin ini sukses melakukan apa yang diucapkannya, apakah nyata merealisasikan janjinya, dan apakah ada jarak yang lebar antara ucapan dengan perbuatan. Agar tidak bias ukuran ini bisa dikuantifikasikan, atau dibuat semacam sekala dengan mempertimbangkan fakta yang terjadi.

2) Sikap atau attitude Ukuran ini bisa dilihat dengan bagaimana perilaku khas sang pemimpin ketika merespons berbagai macam kondisi dan umpan balik yang diterimanya. Apakah sang pemimpin merespon dengan perilaku yang negatif? Atau sebaliknya menyikapi dengan tindakan yang proaktif? Sebagaimana pada ukuran pertama, poin kedua ini bisa dikuantifikasikan agar memberikan hasil yang relatif objektif dan mengurangi risiko multitafsir yang berdampak kepada adu mulut yang tidak perlu.

3) Pengaruh Jika sang pemimpin memiliki skor positif yang tinggi pada kedua ukuran sebelumnya, maka bisa dipastikan ia akan sanggup memiliki ukuran ketiga ini. Pengaruh yang dimaksud disini adalah, apa yang terjadi 
Jurnal Sains Riset (JSR)

p-ISSN 2088-0952, e-ISSN 2714-531X

http://journal.unigha.ac.id/index.php/JSR

DOI. $10.47647 /$ jsr.v10i12

ketika sang pemimpin ada di tengahtengah anggota tim dan apa yang terjadi ketika pemimpin tersebut tidak ada di antara pegawai yang dipimpinnya. Jika yang terjadi adalah pegawai tetap melaksanakan tugas dengan baik ketika pemimpin tidak hadir, maka bisa dipastikan pemimpin tersebut mampu menghadirkan pengaruhnya, meski secara fisik dia tidak ada. Dan ketika yang terjadi adalah sebaliknya, pemimpin tersebut tidak dianggap ada meskipun dia hadir, maka Anda bisa menilai sendiri kualitas dan kemampuan si pemimpin tersebut, karena bukankah Kepemimpinan adalah kemampuan untuk mempengaruhi.

4) Hasil, bagaimanapun seorang pemimpin tetap dan selamanya akan dituntut menghasilkan sesuatu yang diharapkan oleh instansinya. Hasil bisa berupa profit, pertumbuhan, dan kontribusi positif bagi kemajuan instansi yang dipimpinnya. Intinya hasil tersebut harus bisa dirasakan manfaatnya oleh semua pegawai dan masyarakat di sekitar kecamatan tangse secara nyata bisa dilihat dan dibuktikan. Jika ini yang terjadi, tidak ada lagi perdebatan bahwa benar sang pemimpin ini telah paripurna dengan tugasnya.

Dari hasil penelitian ini mendapatkan jawaban bahwa peran pemimpin atau Kepala Kantor Urusan Agama Tangse dalam menjalankan perannya sebagai figurehead dimana kepala rajin dalam melaksanakan kegiatan-kegiatan yang bersifat legal dan sosial dalam meningkatkan kinerja pegawainya, Kepala KUA patut dan layak untuk dicontohkan pegawainya dalam menjalankan organisasi dengan sungguhsungguh. Dan hasil penelitian juga menunjukkan bahwa kepala KUA Kecamata Tangse dalam menjalankan peran pemimpin bersifat interpersonal yang diukur berdasarkan figur sudah cukup baik. Terbukti kepala KUA kecamatan Tangse dapat menjalankan perannya sebagai figurehead, yakni peranan yang dilakukan untuk mewakili organisasi yang dipimpinannya di dalam setiap kesempatan dan persoalan yang timbul secara formal.

\subsubsection{Hambatan-hambatan dalam meningkatkan kinerja pegawai di kantor urusan agama di kecamatan Tangse.}

Adapun hambatan yang ditemui oleh peneliti terhadap peran pemimpin dalam meningkatkan kinerja pegawai ialah:

Perbedaan latar belakang pendidikan pada sumber daya manusia dalam upanya untuk meningkatkan kinerja para pegawai, Kepala KUA Tangse mengalami kendala yang bersifat internal, dimana kendala tersebut muncul dari tingkat pendidikan masing-masing pegawai yang berbeda. Oleh karena itu menurut penuturan dari Kepala KUA Tangse sendiri bahwa dari perbedaan tingkat pendidikan ini menjadi pengaruh yang cukup menonjol dalam memberikan pemahaman kinerja pada masing-masing pegawai.

Pengawasan yang terdapat di Kecamatan Tangse supaya lebih diperhatikan dan tingkatkan, menginggat bahwa fungsi pengawasan menjadi hal sangat penting bagi pemimpin dalam meningkatkan kinerja pegawai.

Pendidikan merupakan hal yang penting bagi kehidupan seseorang, oleh karena itu kepala KUA sebagai pemimpin telah menyadari bahwa dengan adanya masalah ini, juga terdapat perbedaan 
Jurnal Sains Riset (JSR)

p-ISSN 2088-0952, e-ISSN 2714-531X

http://journal.unigha.ac.id/index.php/JSR

DOI. $10.47647 /$ jsr.v10i12

pemahaman dalam pendelegasian tugas antara camat dengan pegawai.

Masalah pribadi keadaan ekonomi pegawai Selain hambatan yang muncul dari faktor internal, ternyata hambatan lain juga ada yaitu secara eksternal. Hambatan ini di sebabkan dari adanya masalah pribadi seperti keadaan ekonomi pada diri pegawai itu sendiri. Keadaan atau kondisi ekonomi merupakan salah satu hal yang mungkin dapat mempengaruhi kehidupan pegawai baik didalam atau diluar lingkungan kantor.

\section{KESIMPULAN DAN SARAN}

\subsection{KESIMPULAN}

Dalam penelitian yang berjudul peran kepemimpinan dalam meningkatkan kinerja pegawai pada kantor urusan agama di kecamatan tangse dapat disimpulkan sebagai berikut:

2. Kepala Kantor Urusan Agama Tangse dalam menjalankan perannya sebagai figurehead dimana kepala rajin dalam melaksanakan kegiatan-kegiatan yang bersifat legal dan sosial dalam meningkatkan kinerja pegawainya, dan telah memberikan contoh yang baik bagi bawahannya.

3. Perbedaan latar belakang pendidikan pada sumber daya manusia dalam upanya untuk meningkatkan kinerja para pegawai, Kepala KUA Tangse mengalami kendala yang bersifat internal, dimana kendala tersebut muncul dari tingkat pendidikan masingmasing pegawai yang berbeda. Oleh karena itu menurut penuturan dari Kepala KUA Tangse sendiri bahwa dari perbedaan tingkat pendidikan ini menjadi pengaruh yang cukup menonjol dalam memberikan pemahaman kinerja pada masing-masing pegawai.
4. Komunikasi yang baik merupakan langkah dari seorang pemimpin dalam meningkatkan kinerja pegawainya, oleh karena itu komunikasi yang menjadi salah satu pengaruh peran kepala KUA Kecamatan Tangse sudah bisa dikatakan baik dan lancar, apalagi dalam aktivitas komunikasi ini camat cenderung lebih akrab kepada pegawai dan telah menganggap pegawai kantor sudah menjadi bagian yang penting.

5. Kurangnya pengawasan dari pemerintah daerah terhadap kantor urusan agama di Kecamatan Tangse

\subsection{SARAN}

1. Peran pemimpin dalam organisasi mempunyai fungsi yang sangat besar dalam meningkatkan kinerja pegawai di Kantor Urusan Agama kecamatan Tangse, untuk itu hubungan kerja sama sedapat mungkin harus bisa terpelihara dengan baik.

2. Untuk lebih menambah pengetahuan, keahlian dan kecapakan guna meningkatakan kemampuan kinerja pegawai, camat harus lebih memperhatikan dan lebih sering melakukan pendelegasian kepada pegawai yang secara tidak langsung dapat melatih dan memotivasi dalam bekerja.

3. c. Pengawasan dan pembinaan harus ada kepedulian dari pihak kabupaten mengingat Kecamatan Tangse termasuk wilayah pedalaman.

4. Pemimpin harus mengetahui bidang tugas dan kemampuan pegawai agar tidak salah dalam memberikan tugas kepada mereka. Serta lebih sering memberikan pembinaan secara presentatif kepada mereka agar dapat 
Jurnal Sains Riset (JSR)

p-ISSN 2088-0952, e-ISSN 2714-531X

http://journal.unigha.ac.id/index.php/JSR

DOI. $10.47647 /$ jsr.v10i12

mengukur tingkat kemampuan pegawai sebagai evaluasi kerja.

\section{DAFTAR PUSTAKA}

Buku

Anoki Herdian Dito (2010) dengan judul penelitian "pengaruh kompensasi terhadap kepuasan karyawan PT. Slamet Langgeng Purbalingga"

Badeni.(2014). Kepemimpinan dan Perilaku Organisasi. Bandung: Alfabeta

Gunawan,Adisaputro. (2010). Manajemen pemasaran: Analisis untukperancangan strategi pemasaran. Yogyakarta: Sekolah Tinggi IlmuManajemen YKPN.

Sedarmayanti.(2011). Manajemen sumber daya manusia, reformasi birokrasi dan manajemen pegawai negeri sipil (cetakan kelima). Bandung: PT Refika aditama

Mathis, R.L. \& J.H. Jackson. 2011. Human Resource Management: Manajemen Sumber Daya Manusia. Terjemahan Dian Angelia. Jakarta: Salemba Empat

Moleong, lexy, (2014).Metode penilitian kualitatif. Bandung: PT. Remaja Rosdakarya

Wibowo (2012) Manajemen Kinerja (edisi ke3) Jakarta: Rajawali Pers.

Sugiyono. (2010) Metode penilitian kualitatif dan kuantitatif dan R\&D Bandung: alfabeta.

(2014) Metode penilitian kualitatif dan kuantitatif dan R\&D Bandung: alfabeta. 